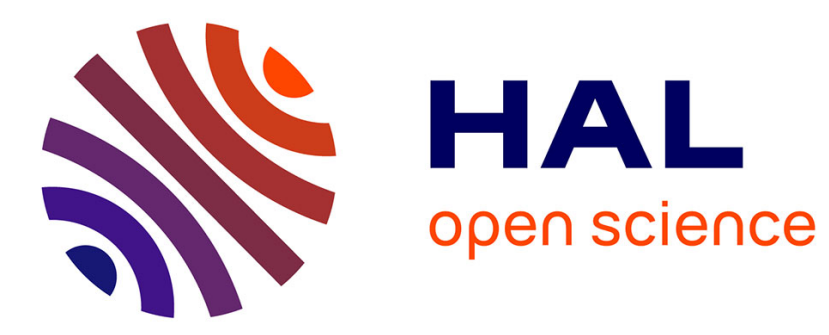

\title{
Does plant flammability differ between leaf and litter bed scale? Role of fuel characteristics and consequences for flammability assessment
}

\author{
A. Ganteaume
}

\section{- To cite this version:}

A. Ganteaume. Does plant flammability differ between leaf and litter bed scale? Role of fuel characteristics and consequences for flammability assessment. International Journal of Wildland Fire, 2018, 27 (5), pp.342-352. 10.1071/WF17001 . hal-02067991

HAL Id: hal-02067991

https://hal.science/hal-02067991

Submitted on 14 Mar 2019

HAL is a multi-disciplinary open access archive for the deposit and dissemination of scientific research documents, whether they are published or not. The documents may come from teaching and research institutions in France or abroad, or from public or private research centers.
L'archive ouverte pluridisciplinaire HAL, est destinée au dépôt et à la diffusion de documents scientifiques de niveau recherche, publiés ou non, émanant des établissements d'enseignement et de recherche français ou étrangers, des laboratoires publics ou privés. 
Author-produced version of the article published in International Journal of Wildland Fire, 2017, 27, 5, 342-352. The original publication is available at http://www.publish.csiro.au/wf/WF17001

DOI: 10.1071/WF17001

1 Does plant flammability differ between leaf and litter bed scale? Role of fuel

2 characteristics and consequences for flammability assessment

3 Anne Ganteaume

4 Irstea, UR RECOVER-EMR, CS 40061, 13182 Aix-en-Provence, France

$5 \quad$ anne.ganteaume@irstea.fr

6

7 Running head

8 Plant flammability can differ between fuel scales

9

10

11 


\begin{abstract}
.
The increasing concern regarding fire in the wildland-urban interface (WUI) around the world highlights the need to better understand the flammability of WUI fuels. Research on plant flammability is rapidly increasing but commonly only considers a single fuel scale. In some cases, however, different fuel scales (e.g. leaf and litter bed) have greater influence on fire, for instance, when it spreads from the litter bed to the lower canopy. Examining fuel flammability at these different scales is necessary to better know the overall flammability but also provides insights into the drivers of flammability. To investigate if leaf and litter bed flammability differed, laboratory experiments were conducted on fifteen species (native or exotic) commonly found in WUI of southeastern France. Species were ranked and the association of fuel characteristics with flammability sought at both scales. For most species, leaf and litter bed flammability differed due to strong fuel characteristics (e.g. leaf thickness or litter bulk density), entailing differences in rankings based on fuel scale and potentially leading to a misrepresentation of flammability of the species studied. Favoring species with lower flammability at both scales in WUI, especially near housing, may help reduce undesired impacts during wildfires.
\end{abstract}

\title{
Brief summary
}

For most species, leaf and litter bed differed in flammability; leaf thickness and litter bulk density being among the main drivers. Low flammable species, at both scales, should be favored in WUI to mitigate damage on housing during wildfires.

Key-words: fuel scale, wildland-urban interface, leaf characteristics, flammability component, litter bulk density, litter composition. 


\section{Introduction}

Around the world, and especially in the Mediterranean region, concerns about the impact of wildland fires are increasingly focusing on the wildland-urban interface (WUI) (Cohen 2000; Lampin-Maillet 2009). Fire occurrence in WUI is highest, being mainly human-induced, and the risks to human lives and property are greatest (Bar Massada et al. 2009). Furthermore, the on-going higher incidence of extreme climate events (e.g. high summer temperatures, strong winds, and drought) is expected to worsen under climate change. This combined with the high flammability of Mediterranean fuels (Valette 1990; Dimitrakopoulos and Papaioannou 2001) implies a higher probability of ignition. Fire propagation throughout WUI vegetation is a growing concern in many regions of the world, especially regarding the structure of ornamental vegetation around housing which can affect its vulnerability. Indeed, this vegetation can act as a vector of fire propagation from wildland fuels to buildings, as well as from one building to another (Etlinger and Beall 2004).

These circumstances led to recommendations for using less flammable species as ornamental plants (Monroe et al. 2003; Long et al. 2006; White and Zipperer 2010). According to Dimitrakopoulos (2001) and to Dimitrakopoulos and Papaiannou (2001), the classification of fuels, in relation to its expected flammability, is an essential component of fire risk assessment (specifically regarding fire hazard). In previous works, flammability rankings of species were mostly performed using ground samples (Dimitrakopoulos and Papaiannou 2001; Liodakis et al. 2002), litter samples (Ganteaume et al. 2013a), leaf and shoot samples (Weise et al. 2005; Ganteaume et al. 2013b; Wyse et al. 2016), and were based only on leaf and litter traits (Behm et al. 2004) or only on experts' opinions (Fogarty 2001). However, none of these works compared litter bed and leaf flammability rankings of species.

Plant flammability has been widely studied and experimentally assessed under laboratory conditions, through different flammability parameters (e.g. time-to-ignition, flaming duration, flame height, flame propagation) recorded during burning experiments, for various purposes and following several methods (Anderson 1970; Martin et al. 1993; Liodakis et al. 2002; Etlinger and Beall 2004; Weise et al. 2005; White and Zipperer 2010). Most works have focused on assessing flammability at the leaf (Dimitrakopoulos and Papaioannou 2001; Liodakis et al. 2002) or the litter bed scale (Scarff and Westoby 2006; Kane et al. 2008; Ganteaume et al. 2011a, 2014; de Magalhães and Schwilk 2012). Litter beds are composed of one or several types of particles and are highly involved in surface fires, or can act as a receptor for firebrands from spot fires (Ganteaume et al. 2009). In some cases, however, different fuel scales are relevant to ignition and fire spread, for example, when it propagates from the litter bed to the lower canopy, transitioning from a surface fire to a crown fire. In this case, the flammability assessment of both live fuel and dead surface fuel (litter) needs to be considered. Moreover, flammability has mostly been assessed using only one flammability variable usually related to fuel ignitability (Valette 1990; Dimitrakopoulos and Papaioannou 
2001), time-to-ignition for instance, thereby lacking evaluation of other variables. The results obtained have also differed depending on the fuel scale considered (Etlinger and Beall 2004; Madrigal et al. 2013) and on the sampling methodology (Ganteaume et al. 2014). Furthermore, the flammability drivers also differed according to flammability parameters and fuel scales examined. Usually, these drivers encompassed morphological and chemical traits at the leaf scale, as well as factors taking into account fuel structure (e.g. bulk density, packing ratio, fuel depth) and fuel composition (proportion of the different fuel components) at the multi-particle scale (Scarff and Westoby 2006; Ganteaume et al. 2011a; Engber and Varner 2012; de Magalhães and Schwilk 2012; Ganteaume et al. 2013a, 2013b, 2014). However, some leaf traits continue to affect litter flammability, scaling up from leaf to litter (Varner et al. 2015).

In order to improve the characterization of species flammability, several flammability parameters across the main fuel scales typically involved in fire propagation should be taken into account. The live leaf and litter bed scales are often among the main fuel scales involved in fire propagation (related to crown fires, surface fires, and spot fires) in WUI and the combination of different methods for assessing their flammability was thus necessary. The objectives of the current work were: (i) to determine the main drivers of flammability (e.g. fuel characteristics) at the leaf and litter bed scales, (ii) to examine if leaf characteristics explained flammability at the litter bed scale, and (iii) to assess whether the ranking of flammability among species differed between scales. These objectives were addressed using fifteen commonly occurring species in WUI of southeastern France. The results can also be relevant in other fire-prone regions, especially given the fact that plant flammability might differ between fuel scales. At a finer scale, results from the current work will also provide a better characterization of the flammability of WUI plants, allowing selection of firesmart species for landscaping. Equally, these results can be of interest outside the framework of WUI, given the range of native and exotic species.

\section{Material and methods}

This work was conducted in the "département" Bouches du Rhône, located in the eastern part of SE France, which is among the areas most affected by wildfires (223 fires and 1266 hectares burned per year during the 2000-2016 period according to the regional forest fire database Prométhée; www.promethee.com). A survey of the most common species planted in WUI was made throughout the study area. I selected 15 of the 20 most representative species of the study area: Viburnum tinus Linnaeus, Prunus laurocerasus Linnaeus (cherry laurel), Cotoneaster franchetii Bois, Pyracantha coccinea Roemer (scarlet firethorn), Elaeagnus ebbingei Doorenbos, Cupressus sempervirens Linnaeus (Italian cypress), C. arizonica Greene, 
Cupressocyparis leylandii (Jacks. \& Dallimore) Farjon, Thuja occidentalis Linnaeus, Nerium oleander Linnaeus (oleander), Photinia fraseri Dress (Christmas berry), Ligustrum japonicum Thunberg (Japanese privet), Euonymus japonicus Thunberg, and Pittosporum tobira (Thunberg) Aiton (Pittosporum). Phyllostachys sp. (bamboo) was also chosen because of its uniqueness, as it was the only monocotyledon recorded during the survey and may present particular flammability characteristics. Most species are native to different regions of the Mediterranean basin (Viburnum tinus common throughout the entire Mediterranean area, Nerium oleander in Spain and Portugal, and Cupressus sempervirens can form monospecific forest stands in Italy and Greece). Other species are native to non-Mediterranean areas (Cupressus arizonica, Thuja occidentalis, or Phyllostachys sp.).

\section{Field sampling}

Sampling was carried out in summer during the fire season (most severe climate conditions). Following the protocol described in Ganteaume et al. (2013a), litter samples (18 x $20 \mathrm{~cm}$ ) were collected undisturbed (thereby containing both litter and duff layers) under hedges to take into account the intact fuel structure and composition. Previous work has highlighted that fuel microstructure affects litter flammability (Ganteaume et al. 2011a). Litter samples were verified to be mainly composed of particles coming from the species studied. Before burning, samples were oven-dried for $48 \mathrm{~h}$ at $60^{\circ} \mathrm{C}$ to reduce fuel moisture content (FMC) that could impact flammability (Chuvieco et al. 2004), and to increase consistency across species. Working with samples with low FMC $(<5 \%)$ was also consistent with that of severe summer climatic conditions (see Ganteaume et al. 2013a). Litter bulk density (BD, in $\mathrm{kg} \mathrm{m}^{-3}$, calculated for each sample by dividing the weight by the volume of the litter sample) was measured and litter components (proportions ${ }^{1}$ of evergreen leaves, scale-leaves, fine and coarse particles, fine and coarse ${ }^{2}$ debris, and non-combustible particles) were sorted from subsamples (for the litter component classes; see Ganteaume et al. 2013a).

Leaves of similar size were collected on mature plants, excluding the newly developed tissues at the top of the twigs. In order to create the worst case scenario in terms of fire risk, each species was sampled in summer at the hottest time of day (between 1200 and 1400), avoiding days following rainfall events. The leaves sampled were placed in plastic bags and stored in a cool box for transportation to the laboratory, minimizing changes in water content. Just before burning, a $5 \mathrm{~g}$ sample of live leaves (fresh weight) of each species was oven-dried for $24 \mathrm{~h}$ at $60^{\circ} \mathrm{C}$ to enable the calculation of FMC.

\footnotetext{
${ }^{1}$ Proportions based on the dry weight of each class of particle.

${ }^{2}$ Debris or particles were defined as fine, when their thickness or diameter was less than $2 \mathrm{~mm}$, and as coarse, when it was higher.
} 
Immediately before burning, the following physical characteristics of the live leaves ${ }^{3}$ were measured because of the importance of particle geometry in determining their combustion: weight (W, in $\mathrm{g}$ ); total $^{4}$ and contact ${ }^{5}$ surface areas (Stot and Sctc, in $\mathrm{cm}^{2}$ ); volume $\left(\mathrm{V}\right.$, in $\left.\mathrm{cm}^{3}\right)$, calculated for the broadleaved species by multiplying leaf thickness by the upper or lower leaf surface area (e.g. contact surface area); weight-to-volume ratio, hereafter referred to as leaf density ( $\mathrm{D}$, in $\mathrm{g} \mathrm{cm}^{-3}$ ); specific leaf area (SLA in $\mathrm{cm}^{2} \mathrm{~g}^{-1}$ ), calculated as the surface area-to-weight ratio; surface area-to-volume ratio (SVR, in $\left.\mathrm{cm}^{-1}\right)$. Because of its impact on fuel ignitability (Montgomery and Cheo 1971), leaf thickness (Thi, in $\mathrm{cm}$ ) was measured at the middle of the leaf (excluding the midrib), using a $10^{-4} \mathrm{~m}$ accuracy micrometer. Leaf surface area and scale-leaf volume were measured using a 2400 dpi scanner and image analysis software (WinFOLIA for leaf surface area and WinSEEDLE for the volume of scale-leaves; Regent Instruments, Canada).

\section{Flammability experiments}

The burning experiments were conducted at the Irstea Aix-en-Provence facility. Air temperature and relative humidity in the laboratory were measured (respectively $27.6 \pm 1.6^{\circ} \mathrm{C}$ and $47.2 \pm 5 \%$ ) throughout the experiment period but they did not affect flammability (Fisher's LSD test, $\mathrm{p}>0.05$ ).

To assess the flammability of live leaves, fifty $1 \pm 0.1 \mathrm{~g}$ samples of each species were burned on an epiradiator that consisted of a $500 \mathrm{~W}$ electric radiator with a $10 \mathrm{~cm}$ diameter radiant disk, as described in previous works (e.g. Hernando-Lara 2000; Ganteaume et al. 2013b). Using heavier samples may increase the possibility that other fuel properties, such as fuel height, would be involved in flammability changes (Ormeño et al. 2009). The surface temperature achieved with the device at a steady-state regime was $420^{\circ} \mathrm{C}$ and the samples were in direct contact with the radiant disk. The contact surface area depended on species whose leaves could shrink and curl up (and even flicker), especially during pyrolysis. However, this contact surface area was assumed to be close enough to the heat source to undergo homogeneous heat transfer effects (mostly by radiation and conduction). A pilot flame which did not take part in the sample decay was located $4 \mathrm{~cm}$ above the centre of the disk; it allowed more regular ignition of the gases emitted during leaf combustion. When the leaf samples were placed on the electric radiator, time-to-ignition (Lv_TTI, in s), then timeto-flame extinction were recorded to enable calculation of flaming duration (Lv_FD, in s).

\footnotetext{
${ }^{3}$ The shape of scale-leaf was approximated as an ellipsoid.

${ }^{4}$ For ordinary flat, non-succulent leaves, the surface area $S$ of the upper surface is approximately equal to that of the lower surface and the total leaf surface $=2 S$.

${ }^{5}$ The contact surface area was the part of the total surface area in contact with the radiant disk (e.g. one-sided projected area).
} 
Ignition frequency ( $\mathrm{Lv} \_\mathrm{IF}$, in \%) was calculated as the percentage of tests in which the samples successfully ignited.

Litter burning experiments (30 undisturbed litter samples by species) were conducted to estimate litter flammability characteristics among species, including ignition and initial fire propagation. To represent similar conditions as during a spot fire, a "standard" glowing firebrand made of Pinus sylvestris wood $(2 \times 2 \times 1 \mathrm{~cm}$, weighing $1.44 \pm 0.05 \mathrm{~g})$ was used as the ignition source and a $9.8 \mathrm{~km} \mathrm{~h}^{-1}$ wind speed was added to the burning device to favor ignition, as described in Ganteaume et al. (2013a). Once flaming ended, the glowing firebrand was placed in the centre of the sample and the timer was initiated. For each litter sample, up to three successive ignition trials were performed until the sample ignited and, as in previous studies (Plucinski and Anderson 2008; Ganteaume et al. 2009, 2011a, 2011b), ignition was considered successful if a flame lasted at least $10 \mathrm{~s}$ to ensure that the ignition was sufficient to allow propagating flames. The variables recorded during the burning experiments were: (i) ignition frequency (Lit_IF, in \%) which was computed as the percentage of tests in which the samples successfully ignited; (ii) time-to-ignition (Lit_TTI, in s) which corresponded to the time necessary for the appearance of a flame after the firebrand had been placed on the sample; (iii) flame propagation which was approximated by the number of opposite directions of the sample reached by flames (Lit_FS, 0 to 4), and (iv) flaming duration (Lit_FD, in s) between the ignition and the end of the flaming combustion (when the timer was stopped).

\section{Data analysis}

In order to highlight the best flammability drivers for both fuel scales, relationships between fuel characteristics and flammability variables were sought using bivariate regression analyses (either the correlation coefficient $\mathrm{R}$ or the adjusted $\mathrm{R}^{2}$ were given in the analyses).

Principal components analysis (PCA) was run on the leaf, then on litter characteristics of the fifteen species to determine their most significant characteristics. The same analysis was also used to investigate flammability patterns across species, regarding both fuel scales, in identifying which litter or leaf flammability variable(s) better characterized the species studied.

Multivariate redundancy analysis (RDA) was performed to examine if leaf characteristics explained flammability at the litter bed scale and to account for the interrelatedness between leaf and litter characteristics in contributing to litter flammability. This analysis summarizes linear relationships between components of dependent variables (flammability) that were "explained" by a set of explanatory factors (fuel characteristics), only when they were significantly correlated.

Using hierarchical cluster analysis (Ward method, based on squared Euclidian distance), the species studied were ranked according to their leaf and litter flammability. For each fuel 
scale, this analysis was used to group species into categories of flammability in such a way that two species from the same cluster were more similar than two species from different clusters, regarding their flammability variables. A total ranking was also obtained, combining all the flammability variables of both fuel scales to obtain an overall "relative" flammability. To account for any difference in flammability, the leaf and litter rankings were compared together, via a Spearman's rank-order correlation which measured the strength of the association between two ranked variables $\left(\mathrm{H}_{0}\right.$ : no association between the two variables).

Except for RDA which was performed in the "vegan" package (R Development Core Team, 2005), the other analyses were performed using Statgraphics ${ }^{\circledR}$ Centurion XV (StatPoint Technologies, Inc, USA).

\section{Results}

\section{Drivers of leaf and litter flammability}

Significant relationships between flammability variables and fuel characteristics were sought for both fuel scales. Regarding leaf flammability, the significant predictors of time-to-ignition were leaf thickness and specific leaf area $\left(R^{2}=0.55, p<0.001 ; R^{2}=0.24, p<0.05\right.$, respectively; Fig. 1a and $1 b$ ). In contrast to thickness, specific leaf area was negatively related to time-toignition, meaning that thin leaves presenting a high specific leaf area quickly ignited whereas thick leaves (mainly scale-leaves of Cupressaceae species), whose specific leaf area was lower, took longer to ignite. Significant negative relationships (but quite moderate) were also detected between leaf flaming duration and both leaf weight and total surface area $\left(\mathrm{R}^{2}=0.23\right.$, $\mathrm{p}<0.05 ; \mathrm{R}^{2}=0.22, \mathrm{p}<0.05$, respectively; Fig. $1 \mathrm{c}$ and $1 \mathrm{~d}$ ), meaning that small light leaves (e.g. Cotoneaster franchetii or Pyracantha coccinea. Suppl. Mat. 1) burned longer than large heavy ones (e.g. Prunus laurocerasus or Cupressus arizonica. Suppl. Mat. 1). Ignition frequency was unrelated to any leaf characteristics. FMC ranged between 72 and $213 \%$ among species but was surprisingly not significantly related to any of the leaf flammability variables. However, when the scale-leaved species were excluded from the analyses, a significant positive relationship between time-to-ignition and FMC was highlighted (Table 1), confirming that leaves with high moisture content took longer to ignite (e.g. Ligustrum japonicum and Nerium oleander. Suppl. Mat. 1). In that case, leaf ignition frequency became negatively correlated with leaf time-to-ignition (Table 2), among the broadleaved species, leaves igniting frequently also ignited quickly (e.g. C. franchetii or Photinia fraseri contrary to Pittosporum tobira and L. japonicum. Suppl. Mat. 1). Leaf characteristics significantly correlated with each other, except FMC (only correlated with specific leaf area when the Cupressaceae species were excluded from the dataset) and leaf density (only correlated with leaf thickness for the complete dataset) (Suppl. Mat. 2). 
Regarding litter flammability, bulk density and proportion of fine debris were the best predictors of flaming duration (but with quite moderate relationships: $R^{2}=0.29, p<0.05$; $\mathrm{R}^{2}=0.25, \mathrm{p}<0.05$, respectively; Fig. 1e and 1f). Compacted litter (corresponding especially to that of Cupressaceae species) tended to have a higher residency time for the fire (Suppl. Mat. 3). These two litter characteristics were positively correlated with each other (Suppl. Mat. 4). Litter that was more compacted tended to have a higher proportion of fine debris. Ignition frequency was negatively correlated with proportion of evergreen leaves $\left(R^{2}=0.25, p<0.05\right.$. Fig. 1g), meaning that litter presenting a large amount of evergreen leaves (e.g. Eleagnus ebbingei) ignited less frequently compared to scale-leaved species litter (Suppl. Mat. 3). Ignition frequency, time-to-ignition, and flame spread were not significantly related to any litter characteristics although some of the correlations were moderate (correlation coefficients around 0.5; Table1). Considering only the broad-leaved species, a significant positive correlation was highlighted between flame spread and proportion of coarse debris (Table1). It is worth noting the positive correlation between litter ignition frequency and flaming duration $\left(\mathrm{R}^{2}=0.59, \mathrm{p}<0.05\right.$; Table 2), showing that species that frequently ignited also burned the longest (e.g. Cupressus species or Photinia fraseri. Suppl. Mat. 3).

The main fuel characteristics of each species were sought for both fuel scales using principal component analyses. For leaves, component 1 explained 52\% of the variation and opposed species with high leaf surface area-to-volume ratio and specific leaf area (such as $P$. coccinea and $C$. franchetii) to those with high leaf volume and surface areas (such as $P$. laurocerasus). Component 2 explained $25 \%$ of the variation and opposed species characterized by leaf thickness and density (Cupressaceae species presenting the highest values contrary to most broadleaved species). FMC best characterized component 3 (explaining only $10 \%$ of the variance) which opposed species, such as L. japonicum, $N$. oleander or P. tobira (high leaf moisture content), to species, such as Photinia fraseri and $C$. franchetii, whose leaves presented lower values of FMC (Suppl. Mat. 5). For litter, component 1explained 38\% of the variation and opposed the Cupressaceae species (scaleleaved species), whose litter presented the highest bulk density and proportion of fine debris, to the broadleaved species whose litter presented high proportion of evergreen leaves (e.g. Elaeagnus ebbingei and Euonymus japonicus). Component 2 (explaining 22\% of the variation) displayed species opposed by the proportion of coarse debris in the litter (e.g. the lowest values were obtained by C. sempervirens contrary to L. japonicum and Phyllostachys sp.). Component 3 (explaining 19\% of the variation) best displayed litter of $C$. franchetii and $P$. tobira that presented the highest proportion of coarse particles and the lowest proportion of non-combustible particles (that showed the highest scores on this component) (Suppl. Mat. 6). 
(a)

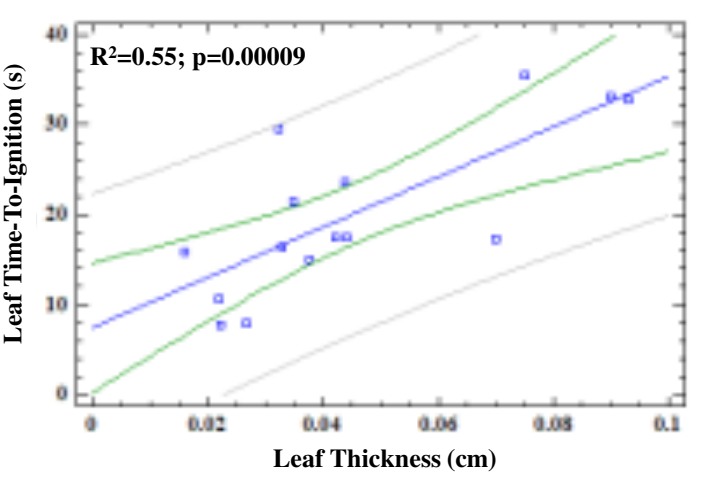

(c)

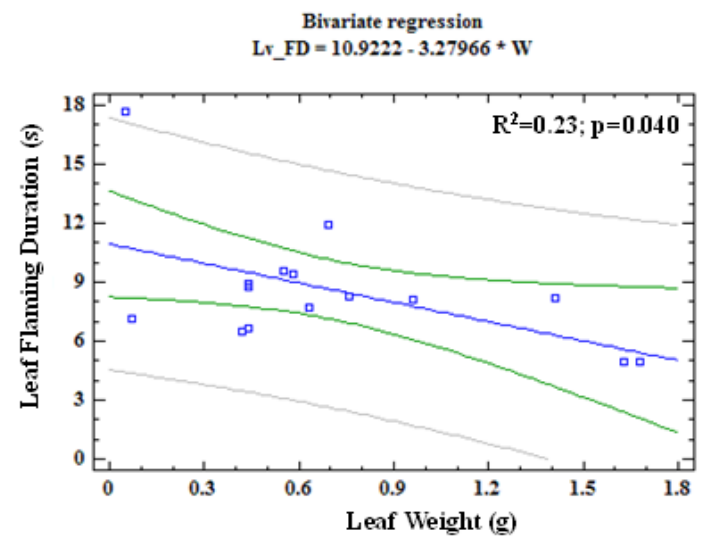

(e)

Bivariate regression Lit_FD $=77.745+0.479715 *$ Lit_BD

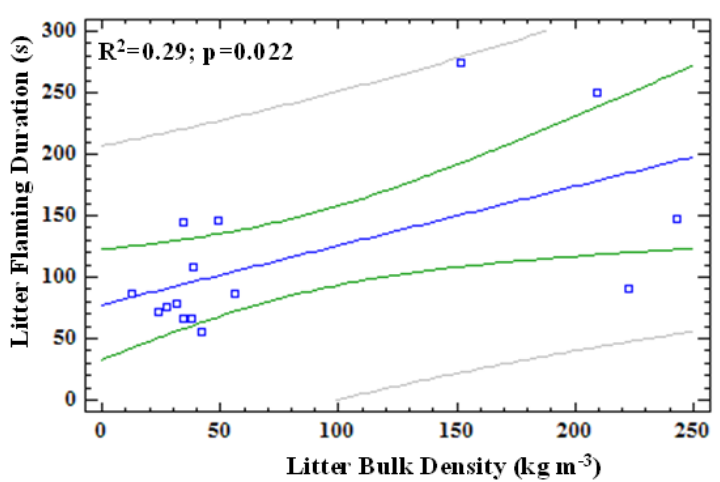

(b)

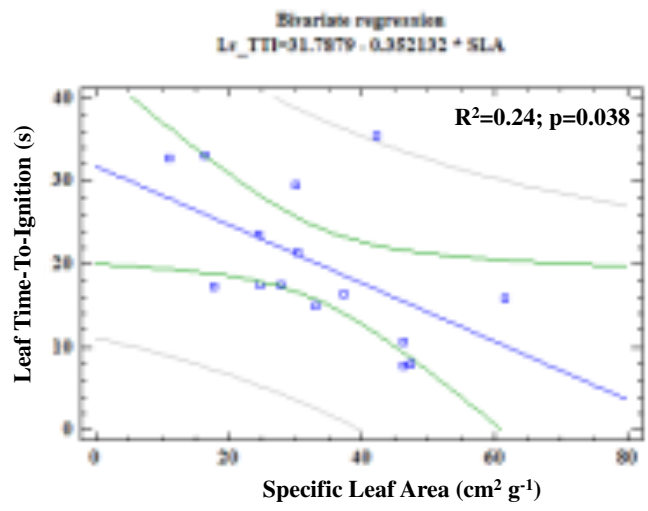

(d)



(f)

Bivariate regression Lit_FD $=79.0844+1.37851 * \% \mathrm{Fd}$

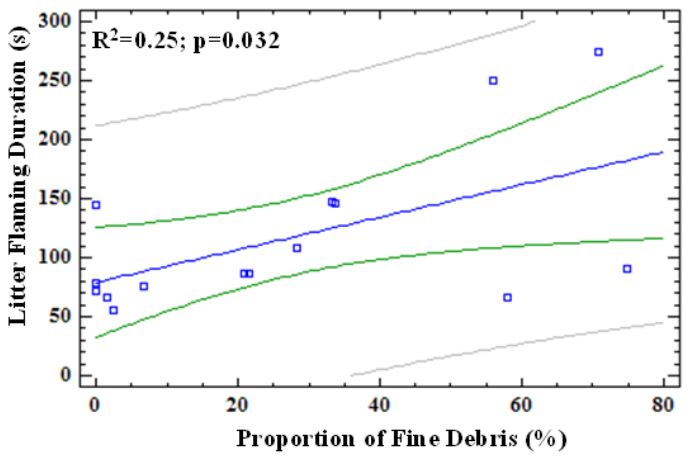


(g)

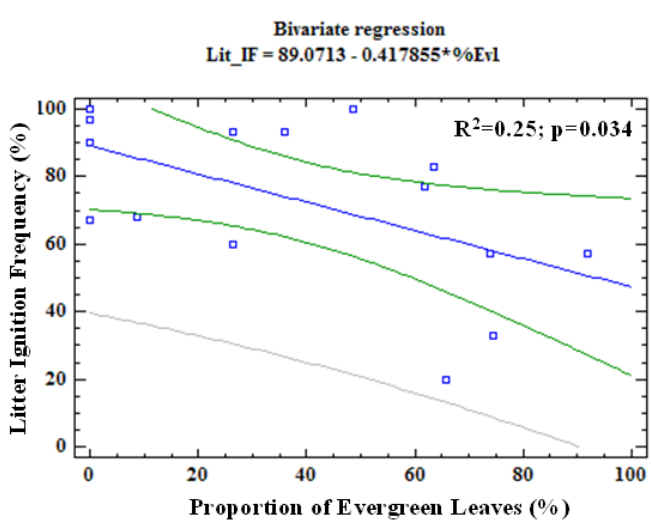

(i)

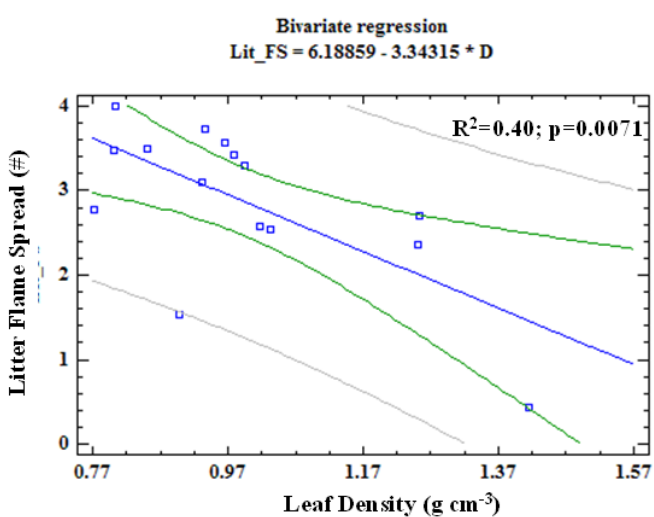

(h)

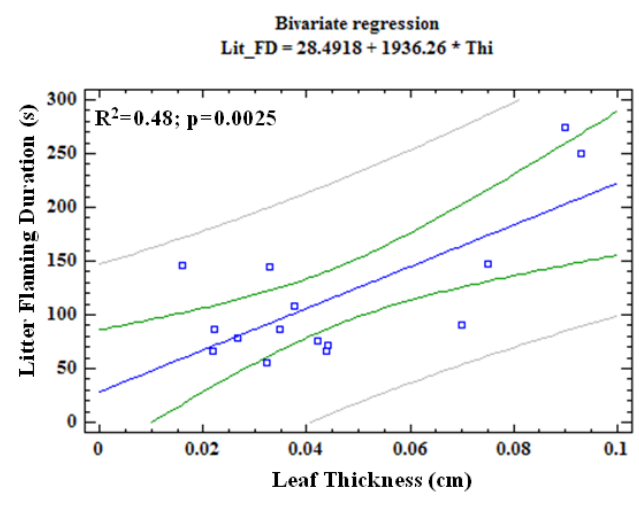

(j)

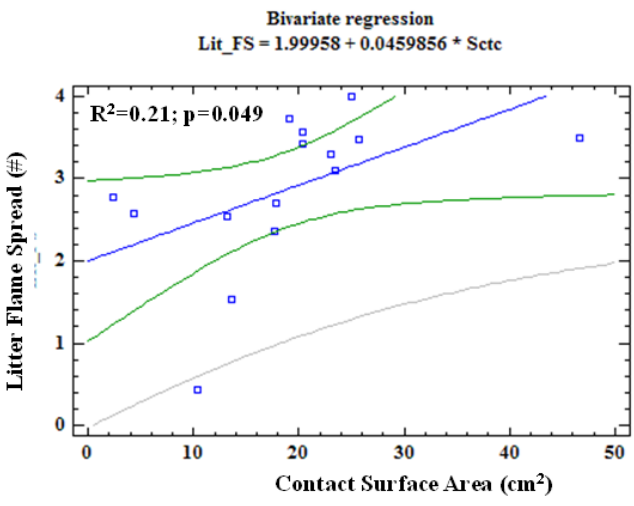

Fig. 1. Significant relationships between leaf and litter characteristics and flammability variables: at the leaf scale (a) leaf thickness (Thi) and leaf time-to-ignition (Lv_TTI), (b) Specific leaf area (SLA) and leaf timeto-ignition (Lv_TTI), (c) leaf weight (W) and leaf flaming duration (Lv_FD), (d) leaf total surface area (Stot) and leaf flaming duration (Lv_FD); at the litter scale (e) litter bulk density (Lit_BD) and litter flaming duration (Lit_FD), (f) proportion of fine debris (\%Fd) and litter flaming duration (Lit_FD), (g) proportion of evergreen leaves (\%Ev) and litter ignition frequency (Lit_IF); at both scales (h) leaf thickness (Thi) and litter flaming duration (Lit_FD), (i) leaf density (D) and litter flame spread (Lit_FS), (j) leaf contact surface area (Sctc) and litter flame spread (Lit_FS).

(Bivariate regressions, $\mathrm{p}=\mathrm{p}$-value, $\mathrm{R}^{2}$ mentioned is the adjusted regression coefficient) 


\section{Influence of leaf characteristics on litter flammability}

297 Some leaf characteristics were significant drivers of litter flammability, but only regarding flaming duration and flame spread (Table 1). Leaf thickness which drove leaf time-to-ignition was also positively related to litter flaming duration $\left(R^{2}=0.48, p<0.01\right.$; Fig. $\left.1 \mathrm{~h}\right)$. This entailed a significant relationship between leaf time-to-ignition and litter flame duration $\left(\mathrm{R}^{2}=0.28\right.$, $\mathrm{p}<0.05$; Table 2), meaning that species whose leaves took longer to ignite also had litter that burned the longest (e.g. Cupressaceae species). Leaf thickness was also highly related to the flaming duration's drivers previously highlighted, especially litter bulk density $(\mathrm{p}<0.0001$, correlation coefficient higher than 0.70. Suppl. Mat. 7). When the scale-leaved species were removed from the dataset, leaf time-to-ignition became negatively correlated with litter ignition frequency (Table 2), meaning that broadleaved species whose leaves took longer to ignite also had litter that did not ignite frequently (e.g. P. tobira). On the contrary, when considering only the scale-leaved species, leaf surface area-to-volume ratio became positively related to litter time-to-ignition as well as leaf total surface area to litter flaming duration and flame spread (Table 1).

Litter flame spread (found unrelated to litter characteristics) was negatively related to leaf density $\left(\mathrm{R}^{2}=0.40, \mathrm{p}<0.01\right.$; Fig. $1 \mathrm{i}$ and Table 1$)$ and positively related to contact surface area $\left(\mathrm{R}^{2}=0.21 \mathrm{p}<0.05\right.$; Fig. $1 \mathrm{j}$ and Table 1$)$. In litter mainly composed of small dense leaves (e.g. T. occidentalis), flames did not propagate well compared to litter composed of large and less dense leaves (e.g. P. laurocerasus, E. ebbingei, or P. fraseri). Several other significant relationships were also highlighted between leaf and litter characteristics that had not been taken into account in the previous analysis as they did not correlate with flammability variables (Suppl. Mat. 7). Most relationships highlighted differences between Cupressaceae species and broadleaved species, such as the positive relationships between the proportion of scale-leaves (characterizing litters of the Cupressaceae species) and both leaf thickness and density (scale-leaves being thicker and denser than evergreen leaves), or between the proportion of fine particles (that better characterized the litter of broadleaved species than those of scale-leaved species) and surface area-to-volume ratio (higher for broadleaves than for scale-leaves).

The interrelatedness among leaf and litter characteristics which was not highlighted in the bivariate regression analyses complicated identifying the contribution of each leaf characteristic to litter characteristics and flammability. The redundancy analysis (RDA) helped to quantify the proportion of variance in flammability explained by all parameters combined for each fuel scale (Fig. 2). The first two RDA axes together explained $83 \%$ of the total variance; $66 \%$ being explained by RDA 1 . This axis displayed the litter flaming duration which was constrained by the combined influence of leaf thickness and weight (the latter to a lesser extent) as well as of litter bulk density and proportion of fine debris. The proportion of 
evergreen leaves in the litter was negatively related to this variable. Component 1 was best characterized by Cupressus arizonica and $C$. leylandii whose litter burned the longest, contrary to that of $P$. tobira, for instance. The score of litter time-to-ignition was higher on RDA 2 (explaining $18 \%$ of the variance) and this variable was mostly constrained by the influence of proportion of fine particles and specific leaf area, to a lesser extent. Litter of $P$. coccinea and L. japonicum best characterized this component, the former presenting the highest proportion of fine particles and taking longer to ignite contrary to the latter.

\section{Characterization of live leaf and litter flammability}

The fifteen species had contrasting flammability but this was not consistent across all parameters and fuel scales (Suppl. Mat. 1 and 3; Fig. 3). Leaf flammability was mainly driven by time-to-ignition and flaming duration which were displayed on opposite sides of the first component (explaining $31 \%$ of the variance), along with litter flaming duration (best characterizing litter flammability). Leaves of $C$. arizonica (longest time-to-ignition) and $C$. franchetii (longest flaming duration) as well as litter of $C$. leylandii (longest flaming duration) were best characterized by these flammability variables (highest scores on the first component). Leaf and litter ignition frequencies were displayed on the second component (explaining $24 \%$ of the variance); leaves of P. tobira and L. japonicum (lowest leaf ignition frequency) as well as litter of $P$. fraseri (highest litter ignition frequency) were best characterized by these variables (highest scores on the second component). Finally, litter time-to-ignition and flame spread were opposed on the third component (explaining 17\% of the variation); litter of E. japonicus and P. coccinea (longest time-to-ignition and low flame spread) as well as those of L. japonicum (shortest time-to ignition and highest flame spread) best characterized these variables (highest scores on the third component). 


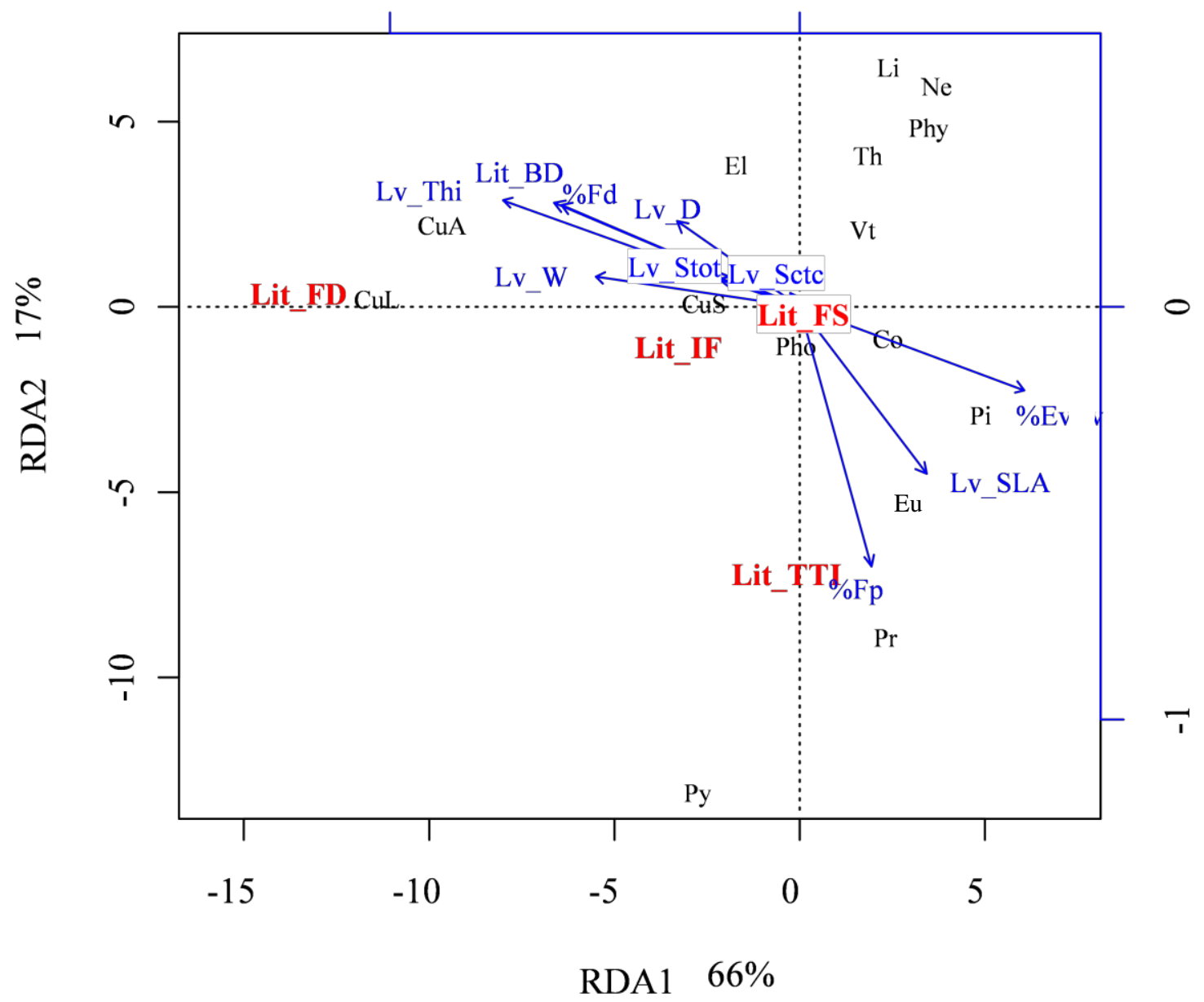

Fig. 2. Redundancy analysis plot run on the litter flammability variables (in bold) as constrained by the litter and leaf characteristics (only those presenting a significant relationships with flammability where taken into account) of the 15 ornamental species.

(Lv: leaf, Lit: litter, Sctc: leaf contact surface area, Stot: leaf total surface area, Thi: leaf thickness, W: leaf weight, SLA: specific leaf area, D: leaf density, BD: litter bulk density, \%Ev: proportion of evergreen leaves, \%Fp: proportion of fine particles, \%Fd: proportion of fine debris, Co: Cotoneaster franchetii, CuA: Cupressus arizonica, CuL: Cupressocyparis leylandii, CuS: Cupressus sempervirens, El: Elaeagnus ebbingei, Eu: Euonymus japonicus, Li: Ligustrum japonicum, Ne: Nerium oleander, Pho: Photinia fraseri, Phy: Phyllostachys sp., Pi: Pittosporum tobira, Pr: Prunus laurocerasus, Py: Pyracantha coccinea, Th: Thuja occidentalis, Vt: Viburnum tinus). 

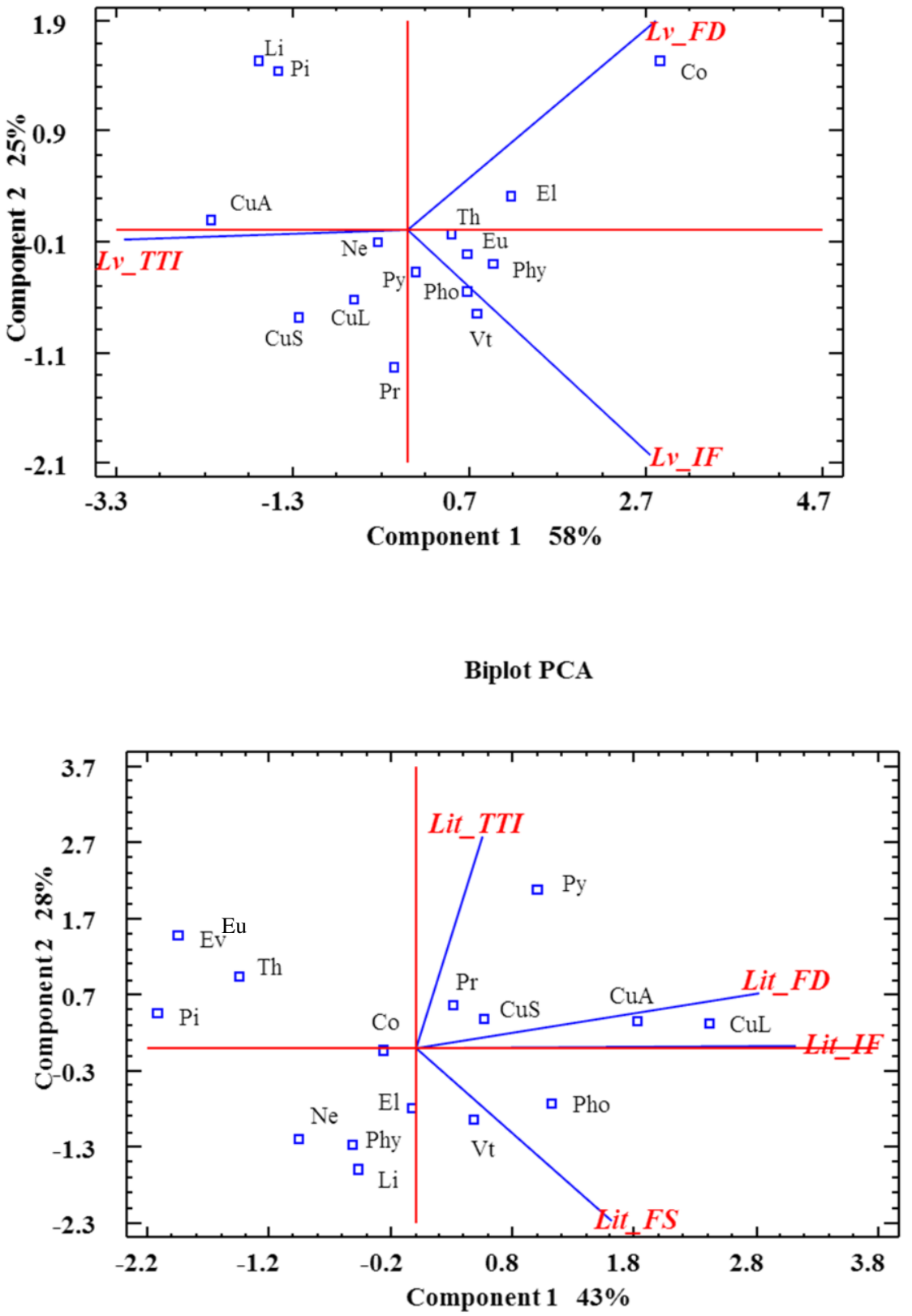

Fig.3. Biplots of the principal component analysis showing relationships between the 15 ornamental species and leaf (a) and litter (b) flammability variables (Lv: leaves, Lit: litter, IF: ignition frequency, TTI: time-to-ignition, FD: flaming duration, FS: flame spread, Co: Cotoneaster franchetii, CuA: Cupressus arizonica, CuL: Cupressocyparis leylandii, CuS: Cupressus sempervirens, El: Elaeagnus ebbingei, Eu: Euonymus japonicus, 
Li: ligustrum japonicum, Ne: Nerium oleander, Pho: Photinia fraseri, Phy: Phyllostachys sp., Pi: Pittosporum tobira, Pr: Prunus laurocerasus, Py: Pyracantha coccinea, Th: Thuja occidentalis, Vt: Viburnum tinus).

\section{Ranking species according to their flammability}

For each ranking (leaf, litter, and total), hierarchical cluster analyses highlighted four groups of species from the most flammable to the least flammable; the composition of these groups differed from one analysis to the other (Fig. 4). For live leaves (Fig. 4a), C. franchetii had the highest flammability (mainly due to long flaming duration and short time-to-ignition) whereas $P$. tobira, C. arizonica, and L. japonicum belonged to the group of the least flammable species (mostly due to longer time-to-ignition and lower ignition frequency). The other species belonged to the two groups of intermediate flammability: leaves of $C$. sempervirens and $C$. leylandii took longer to ignite and the eight other species presented intermediate values of flammability and/or short time-to-ignition or high ignition frequency.

For litter (Fig. 4b), three species composed the group of the least flammable species $(P$. tobira, E. japonicus, and T. occidentalis) which, except for P. tobira, differed from the previous ranking. These species had low ignition frequency and/or long time-to-ignition, short flaming duration, and low flame propagation. The species composing the two groups of intermediate flammability were also different from those of the leaf ranking: $P$. coccinea and $P$. laurocerasus presented long time-to-ignition but high flame spread whereas $C$. arizonica and $C$. leylandii were characterized by long flaming duration and high ignition frequency. The eight other species composed the group of the most flammable species which, except for $C$. franchetii, were different from the leaf ranking (in which this group was composed of this latter species only). These species presented intermediate values of flammability and short time-to-ignition or high flame propagation.

Regarding the total ranking (Fig. 4c), combining both leaf and litter flammability, two species belonged to the group of the least flammable species, including $P$. tobira (as in the two previous rankings) and L. japonicum (as in the leaf ranking) which had the lowest ignitability (e.g. long time-to-ignition and low ignition frequency). In the two groups of intermediate flammability, species differed from those of the previous rankings: the group of the three Cupressus species presented long leaf time-to-ignition but long flaming duration. $E$. japonicus, T. occidentalis, P. coccinea, and P. laurocerasus composed the other group, characterized by short flaming duration and low flame spread but differing in their ignitability (for both time-to-ignition and ignition frequency). The group of the most flammable species was composed of the six other species, still including $C$. franchetii, which were mostly characterized by higher litter and leaf ignitability, long leaf flaming duration, high flame spread or by intermediate values of flammability. 
430

431

432

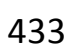

434

435

436

437

438

439

440

441

442

443

444

445

446

447

448

449

450

451

452

453

454

455

According to the Spearman's rank-order correlation, the rankings obtained for leaf and litter flammability were not correlated (results would not change when each flammability variable was taken separately) (Table 3), confirming the results of the hierarchical cluster analyses. This result highlighted a significant difference in the species composition of the different groups of flammability.

(1)
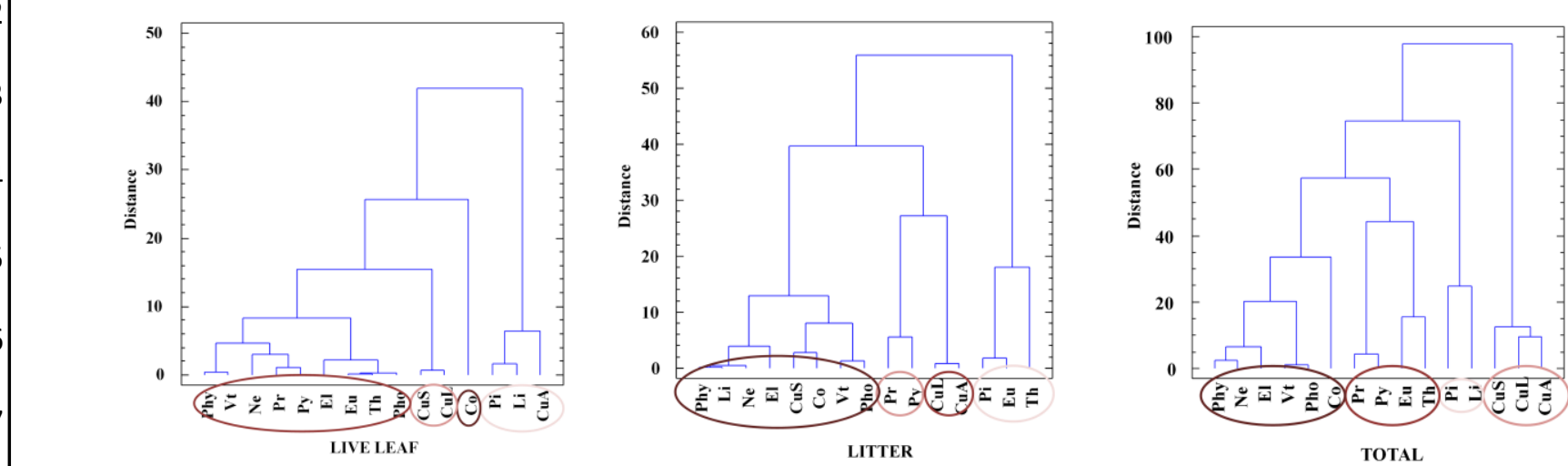

Fig. 4. Rankings of the 15 ornamental species from the most flammable (darkest outline) to the least flammable (lightest outline) species according to the flammability of live leaves (a), litter (b), and both fuels (c) (Co: Cotoneaster franchetii, $\mathrm{CuA}$ : Cupressus arizonica, CuL: Cupressocyparis leylandii, CuS: Cupressus sempervirens, El: Elaeagnus ebbingei , Eu: Euonymus japonicus, Li: Ligustrum japonicum, Ne: Nerium oleander, Pho: Photinia fraseri, Phy: Phyllostachys sp., Pi: Pittosporum tobira, Pr: Prunus laurocerasus, Py: Pyracantha coccinea, Th: Thuja occidentalis, Vt: Viburnum tinus).

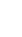


flammability was best characterized by litter flaming duration which was mainly driven by bulk density and proportion of fine debris (especially for $C$. arizonica and C. leylandii). In addition, litter flammability was also characterized by litter ignition frequency which was negatively related to the proportion of evergreen leaves in the litter (especially for P. tobira and E. japonicus). Thick leaves with low specific leaf area (e.g. scale-leaves) took longer to ignite in contrast to thinner leaves with higher specific leaf area, such as those of $C$. franchetii, agreeing with previous works (Montgomery and Cheo 1971; Murray et al. 2013; Grootemaat et al. 2015). Specific leaf area as well as surface area-to-volume ratio (the latter, however, was not significant in the analyses) are essential factors driving ignitability, as with FMC (Bond and Van Wilgen 1996; Anderson and Anderson 2009; White and Zipperer 2010; Marino et al. 2011; Madrigal et al. 2013; Murray et al. 2013; Santoni et al. 2014; Grootemaat et al. 2015). FMC was not a significant predictor of leaf flammability, mostly because it was overridden by leaf thickness, but, when considering only the broad-leaved species (thinner leaves), FMC significantly increased leaf time-to-ignition (as for L. japonicum and $N$. oleander). The range of FMCs recorded in the species studied covered the range of live FMCs in Bond and Van Wilgen (1996; 50-205\%) or in Grootemaat et al. (2015; 68-231\%). Surprisingly, the results also showed that heavy leaves characterized by high total surface area (e.g. P. laurocerasus or C. arizonica) burned for a shorter time than lighter and smaller leaves (e.g. C. franchetii which also ignited faster) contrary to the results of Grootemaat et al. (2015). However, the variation in leaf flaming duration among species explained by leaf weight and total surface area was moderate in the current work $\left(\mathrm{R}^{2}=0.22\right.$ and 0.23$)$.

The most important drivers of litter flammability have been sought among fuel bed characteristics (e.g. "in situ" bulk density and litter components, as litter samples were collected undisturbed) but also among those of leaves. Given their importance in the flammability of surface fuels, the need to scale up from leaf to litter bed characteristics has already been highlighted in previous works (Scarff and Westoby 2006; de Magalhães and Schwilk 2012; Varner et al. 2015). Leaf thickness was among the main drivers of leaf time-toignition and was also a significant predictor of litter flaming duration: litter of thick-leaved species (Cupressaceae species) took longer to burn. This result was not always consistent with other experimental studies (Kane et al. 2008; de Magalhães and Schwilk 2012) in which litter beds composed of thick leaves either were characterized by lower residence time for fire or did not present a specific pattern of flaming duration (results not significant). These thick scale-leaved species also had the most compacted litter (e.g. the highest bulk density). Litter bulk density was positively related to flaming duration, agreeing with the results of de Magalhães and Schwilk (2012) who found that the leaf surface area was also a significant predictor of flaming duration. In the current work, this latter parameter was unrelated to flaming duration (except for the scale-leaved species dataset, but with a positive effect). It is worth noting that leaf thickness (along with leaf density) significantly correlated with litter bulk density because of the thickness (and high density) of scale leaves, scaling up from leaf 
to litter bed characteristics according to other works (Scarff and Westoby 2006; Cornwell et al. 2015). However, leaf density was not related directly to flaming duration as was leaf thickness. Accordingly, these leaves can be easily broken into fine debris (e.g. very small elements) and produce more tightly packed litter that took longer to burn because of the slow combustion mostly due to the lack of oxygen in the samples (Scarff and Westoby 2006; Schwilk and Caprio 2011; de Magalhães and Schwilk 2012). This result also showed the importance of decomposed materials on litter flaming duration (Zhao et al. 2014); this large amount of fine debris resulted from the slow decomposition process characterizing gymnosperms compared to angiosperms (Cornwell et al. 2008). Bulk density was unrelated to litter time-to-ignition, as already highlighted by Santoni et al. (2014). Oxygen limitation in compacted litter samples (high bulk density) should have mitigated the flame propagation, as found in other works (Scarff and Westoby 2006; Santoni et al. 2014) but, surprisingly, flame spread and bulk density were not significantly related. In contrast, leaf contact surface area and density turned out to be significant predictors of flame spread, the former increasing flammability contrary to the latter. In fact, denser leaves presented more fuel to burn, mitigating flame propagation. This result agreed with previous works that showed that litter flammability was often strongly influenced by litter particle (e.g. leaf) size, larger particles leading to greater aeration, faster flame spread rate, and higher rate of heat release (Scarff and Westoby 2006; Kane et al. 2008; van Altena et al. 2012; de Magalhães and Schwilk 2012; Cornwell et al. 2015).

\section{Flammability ranking}

Results showed that only two species had the same flammability, regardless of the fuel scale: the poorly flammable species $P$. tobira, agreeing with White and Zipperer (2010, based on Baptiste 1992), and the highly flammable C. franchetii. However, for most species, the rankings differed between the two fuel scales, some species having more flammable litter than the live leaf scale (e.g. C. sempervirens) and other species demonstrating the opposite pattern (e.g. E. japonicus). In contrast, using a different burning devices, Dimitrakopoulos (2001) ranked $C$. sempervirens' leaves among the most flammable (but measuring only the mean volatilization rate) and Etlinger and Beall (2004, based on the work of Lubin and Shelly 1997) recommended $N$. oleander to be used in high fire hazard areas (but measuring only the peak heat released). Their assessment of the species' flammability would have been more accurate if several flammability components had been taken into account.

Most species were ranked differently depending on the fuel scale: e.g. leaves of $L$. japonicum were poorly flammable whereas this species' litter was highly flammable. Other species presented the opposite pattern (e.g. T. occidentalis). Species composing these groups could also differ from those of the total ranking; e.g. species such as $C$. arizonica or $C$. sempervirens were ranked more flammable in the litter ranking than in the total ranking, 
leading to an underestimation of their flammability if based only on both fuel scales combined. To increase the robustness of flammability estimates, species rankings should encompass multiple relevant scales, with the most severe ranking considered carefully. The most accurate flammability ranking should thus be composed of three groups of species (instead of the four groups previously identified). The group of the most flammable species should be composed of species presenting a higher litter flammability: Cotoneaster franchetii (always ranked as very flammable regardless of the fuel scale), Phyllostachys sp., Photinia fraseri, Viburnum tinus, Eleaegnus ebbingei, Nerium oleander (moderate leaf flammability), and Cupressus sempervirens and Ligustrum japonicum (lower leaf flammability). The group of intermediate flammability should be composed of Pyracantha coccinea, Prunus laurocerasus, Euonymus japonicus, and Thuja occidentalis (moderate leaf flammability) and of Cupressus arizonica and Cupressocyparis leylandii (moderate litter flammability). Regardless of the fuel scale, Pittosporum tobira was consistently poorly flammable and was the only one to compose the group of the least flammable species. For landscaping, the most conservative approach would be to select species that have lower flammability at both scales (in this case, only Pittosporum tobira) or to avoid species with higher flammability (such as Cotoneaster franchetii). Potential limitations of rankings could be underlined, e.g. species burning quickly would likely provoke less damage to structures than others burning slowly (yet ranked less flammable).

C. sempervirens (var. pyramidalis) had a large amount of dead leaves within its crown, due to its fastigiated form (Ganteaume et al. 2013b; Della Rocca et al. 2015), resulting in a high combustibility, thus burning with a far greater intensity when reached by the flames. This result highlights the need to assess, along with the flammability, the proportion of dead and fine particles that composes each species' crown (as in Ganteaume et al. 2013b). In their work, Della Rocca et al. (2015) suggested to plant barrier systems of $C$. sempervirens var. horizontalis in WUI to reduce the fire spread because of this species' low leaf flammability, but without assessing litter flammability (the most flammable fuel scale for $C$. sempervirens according to the current work) nor the amount of dead fuel in the canopy. Even if this amount is smaller in this variety of cypress, the live biomass is still dense and thus could burn with high intensity. Regardless of the variety, C. sempervirens should not be planted close to housing that could be damaged if the plant ignites, as observed by the firefighters.

\section{Explaining differences in results between works}

The differences I found between studies could be explained by the differences in litter type (undisturbed samples vs reconstructed samples), in experimental devices and ignition processes, as well as in the flammability variables recorded (Weise et al. 2005; Madrigal et al. 2013). Laboratory-based flammability measurements are not perfect and may not entirely represent the ecosystems (Fernandes and Cruz 2012), even if the experiments were carried out 
571 on undisturbed litter samples whose structure and composition are kept intact.

572 Complementary information that could be provided at the whole plant scale is needed and 573 may help in the integration and discussion of such results. In the case of the assessment of the

574 whole plant flammability, the influence of plant geometry will have to be analyzed in addition 575 to the other characteristics. Indeed, it is helpful to distinguish between characteristics 576 influencing the flammability of the whole plant's canopy and those that influence the 577 flammability of the litter to which they contribute (Schwilk 2015).

578

579

580

581

582

583

584

585

586

587

588

589

590

591

592

593

594

595

596

597

598

599

600

601

602

603

\section{Acknowledgements}

The author wishes to thank the Irstea's technical staff, Roland Estève, Fabien Guerra and Jean-Michel Lopez, for their contribution in the field and in the laboratory during the burning experiments. The author also sincerely thanks Aimee Mac Cormack for English revision.

\section{References}

Van Altena C, van Logtestijn RS, Cornwell WK, Cornelissen JHC (2012) Species composition and fire: non-additive mixture effects on ground fuel flammability. Frontiers in Plant Science 3, 1-10.

Anderson HE (1970) Forest fuel ignitability. Fire Technology 6, 312-319.

Anderson SAJ, Anderson WR (2009) Predicting the elevated dead fine fuel moisture content in gorse (Ulex europaeus L.) shrub fuels. Canadian Journal of Forest Research 39, 23552368. doi:10.1139/X09-142

Baptiste L (1992) 'Firescape - landscaping to reduce fire hazard.' East Bay Municipal Utility District: Oakland, CA.

Bar Massada A, Radeloff VC, Stewart SI, Hawbaker TJ (2009) Wildfire risk in the wildlandurban interface: a simulation study in northwestern Wisconsin. Forest Ecology and Management 258, 1990-1999. doi:10.1016/J.FORECO.2009.07.051

Behm AL, Duryea ML, Long AJ, Zipperer WC (2004) Flammability of native understory species in pine flatwood and hardwood hammock ecosystems and implications for the wildland-urban interface. International Journal of Wildland Fire 13, 355-365.

Bond WJ, Van Wilgen BW (1996) Fire and plants. Chapman and Hall. London. 
Chuvieco E, Aguado I, Dimitrakopoulos AP (2004) Conversion of fuel moisture content values to ignition potential for integrated fire danger assessment. Canadian Journal of Forest Research 34, 2284-2293.

Cohen JD (2000) Preventing disaster: home ignitability in the wildland-urban interface. Journal of Forestry 98, 15-21.

Cornwell WK, Elvira A, Van Kenpem L, Van Logtestijn RSP, Aptroot A, Cornelissen JHC (2015) Flammability across the gymnosperm phylogeny: the importance of litter particle size. New Phytologist 206, 672-681.

Cornwell WK, Cornelissen JHC, Amatangelo K, Dorrepaal E, Eviner VT, Godoy O, Hobbie SE, Hoorens B, Kurokawa H, Perez-Harguindeguy N, Quested HM, Santiago LS, Wardle DA, Wright IJ, Aerts R, Allison SD, van Bodegom P, Brovkin V, Chatain A, Callaghan TV, Diaz S, Garnier E, Gurvich DE, Kazakou E, Klein JA, Read J, Reich PB, Soudzilovskaia NA, Vaieretti MV, Westoby M (2008) Plant species traits are the predominant control on litter decomposition rates within biomes worldwide. Ecology Letters 11, 1065-1071.

Della Rocca G, Hernando C, Madrigal J, Danti R, Moya J, Guijarro M, Pecchioli A, Moya B (2015) Possible land management uses of common cypress to reduce wildfire initiation risk: a laboratory study. Journal of Environmental Management 159, 68-77.

Dimitrakopoulos AP (2001) A statistical classification of Mediterranean species based on their flammability components. International Journal of Wildland Fire 10, 113-118.

Dimitrakopoulos AP, Papaioannou KK (2001) Flammability Assessment of Mediterranean Forest Fuels. Fire Technology 37, 143-152.

Engber EA, Varner JM (2012) Patterns of flammability of the California oaks: the role of leaf traits. Canadian Journal of Forest Research 42, 1965-1975.

Etlinger MG, Beall FC (2004) Development of a laboratory protocol for fire performance of landscape plants. International Journal of Wildland Fire 13, 479-488. doi:10.1071/WF04039

Fernandes PM, Cruz MG (2012) Plant flammability experiments offer limited insight into vegetation-fire dynamics interactions. New Phytologist 194, 606-609.

Fogarty LG (2001) A flammability guide for some common New Zealand native tree and shrub species. Forest Research Bulletin 143, Forest and Rural Fire Scientific and Technical Series Report 6. Forest Research Institute in association with the New Zealand Fire Service Commission and National Rural Fire Authority, Rotorua, Wellington. 
Ganteaume A, Jappiot M, Lampin C, Curt T, Borgniet L (2014) Flammability of litter sampled according to two different methods: comparison of results in laboratory experiments. International Journal of Wildland Fire 23, 1061-1075.

Ganteaume A, Jappiot M, Lampin-Maillet C (2013a) Assessing the flammability of surface fuels beneath ornamental vegetation in wildland-urban interface, in Provence (southeastern France). International Journal of Wildland Fire 22, 333-342.

Ganteaume A, Jappiot M, Lampin C, Guijarro M, Hernando C (2013b) Flammability of Some Ornamental Species in Wildland-Urban Interface in Southeastern France: Laboratory Assessment at Particle Level. Environmental Management 52, 467-480.

Ganteaume A, Jappiot M, Lampin-Maillet C, Curt T, Borgniet L (2011a) Effects of vegetation types and fire regime on flammability of non-constructed litters in south-eastern France. Forest Ecology and Management 261, 2223-2231.

Ganteaume A, Guijarro M, Jappiot M, Hernando C, Lampin-Maillet C, Perez-Gorostiaga P, Vega JA (2011b) Laboratory characterization of firebrands involved in spot fires. Annals of Forest Science 68, 531-541. Doi 10.1007/s13595-011-0056-4

Ganteaume A, Lampin-Maillet C, Guijarro M, Hernando C, Jappiot M, Fonturbel T, PérezGorostiaga P, Vega JA (2009) Spot fires: fuel bed flammability and capability of firebrands to ignite fuel beds. International Journal of Wildland Fire 18, 951-969.

Grootemaat S, Wright I, Van Bodegom P, Cornwell W (2015) Burn or rot: leaf traits explain why flammability and decomposability are decoupled across species. Functional Ecology 29, 1486-1497.

Hernando-Lara C (2000) Combustibles forestales: inflamabilidad. In "La defensa contra incendios forestales, fundamentos y experiencias" (ed. R. Vélez Muñoz), pp. 3-6. McGraw-Hill.

Kane JM, Varner JM, Hiers JK (2008) The burning characteristics of southeastern oaks: Discriminating fire facilitators from fire impeders. Forest Ecology and Management 256, 2039-2045.

Lampin-Maillet C (2009) Caractérisation de la relation entre organisation spatiale d'un territoire et risqué d'incendie: le cas des interface habitat-forêt du sud de la France. $\mathrm{PhD}$ thesis, Université de Provence, Marseille.

Liodakis S, Bakirtzis D, Lois E (2002) TG and auto-ignition studies on forest fuels. Journal of Thermal Analysis and Calorimetry 69, 519-528.

Long AJ, Behm A, Zipperer WC, Hermansen A, Maranghides A, Mell W (2006) Quantifying and ranking the flammability of ornamental shrubs in the southern United States. In "2006 
Fire Ecology and Management Congress Proceedings" (Ed. The Association for Fire Ecology and Washington State University Extension), San Diego, CA.

Lubin DM, Shelly JR (1997) Defensible space landscaping in the urban/wildland interface: a compilation of fire performance ratings of residential landscape plants. Internal Report No. 36.01.137, University of California, Richmond, CA.

Madrigal J, Hernando C, Guijarro M (2013) A new bench-scale methodology for evaluating flammability of live forest fuels. Journal of Fire Science 31 (2), 131-142.

De Magalhães RMQ, Schwilk DW (2012) Leaf traits and litter flammability: evidence for non-additive mixture effects in a temperate forest. Journal of Ecology 100, 1153-1163.

Marino E, Guijarro M, Hernando C, Madrigal J, Díez C (2011) Fire hazard after prescribed burning in a gorse shrubland: implications for fuel management. Journal of Environmental Management 92, 1003-1011.

Martin RE, Gorden DA, Gutierrez ME, Lee DS, Molina DM, Schroeder RA, Sapsis DA, Stephens SL, Chambers M (1993) Assessing the flammability of domestic and wildland vegetation. In "Proceedings of the 12th Conference on Fire and Forest Meteorology", October 26-28, Jekyll Island, Georgia, pp.130-137.

Monroe MC, Long AJ, Marynowski S (2003) Wildland fire in the Southeast: Negotiating guidelines for defensible space. Journal of Forestry 10, 14-19.

Montgomery KR, Cheo PC (1971) Effect of leaf thickness on ignitibility. Forest Science 17, $475-478$.

Murray BR, Hardstaff LK, Phillips ML (2013) Differences in leaf flammability, leaf traits and flammability-trait relationships between native and exotic plant species of dry sclerophyll forest. PLoS ONE 8, e79205.

Nuñez-Regueira L, Rodríguez-Añón JA, Proupín-Castiñeiras J (1996) Calorific values and flammability of forest species in Galicia. Coastal and hillside zones. Bioresource Technology 57, 283-289.

Ormeño E, Céspedes B, Sánchez IA, Velasco-García A, Moreno J, Fernandez C, Baldy V (2009) The relationship between terpenes and flammability of leaf litter. Forest Ecology and Management 257, 471-482.

Plucinski MP, Anderson WR (2008) Laboratory determination of factors influencing successful point ignition in the litter layer of shrubland vegetation. International Journal of Wildland Fire 17, 628-637. 
R Development Core Team (2005) R: A Language and Environment for Statistical Computing, Reference Index Version v. 2.5.1. R Foundation for Statistical Computing, Vienna, Austria.

Santoni PA, Bartoli P, Simeoni A, Torero J (2014) Bulk and particle properties of pine needle fuel beds - influence on combustion. International Journal of Wildland Fire 23, 10761086.

Scarff FR, Westoby M (2006) Leaf litter flammability in some semi-arid Australian woodlands. Functional Ecology 20, 745-752.

Schwilk DW (2015) Dimensions of plant flammability. New Phytologist 206, 486-488.

Schwilk DW, Caprio AC (2011) Scaling from leaf traits to fire behaviour: community composition predicts fire severity in a temperate forest. Journal of Ecology 99, 970-980.

Valette JC (1990) Inflammabilités des espèces forestières méditerranéennes. Revue Forestière Française 42, 76-92.

Varner JM, Kane JM, Kreye JK, Engber E (2015) The flammability of forest and woodland litter: a synthesis. Current Forestry Reports 1: 91-99. doi: 10.1007/s40725-015-0012-x

Weise DR, White RH, Beall FC, Etlinger M (2005) Use of the cone calorimeter to detect seasonal differences in selected combustion characteristics of ornamental vegetation. International Journal of Wildland Fire 14, 321-338. doi:10.1071/WF04035

White RH, Zipperer WC (2010) Testing and classification of individual plants for fire behaviour: plant selection for the wildland-urban interface. International Journal of Wildland Fire 19, 213-227.

White RH, DeMars D, Bishop M (1997) Flammability of Christmas trees and other vegetation. In "Proceedings of the 24th international conference on fire safety" (Ed. C.J. Hilado), pp. 99-110. Columbus, $\mathrm{OH}$.

Wyse SV, Perry GLW, O’Connell DM, Holland PS, Wright MJ, Hosted CL, Whitelock SL, Geary IJ, Maurin KJL, Curran TJ (2016) A quantitative assessment of shoot flammability for 60 tree and shrub species supports rankings based on expert opinion. International Journal of Wildland Fire 25, 466-477.

Zhao W, Blauw LG, van Logtestijn RSP, Cornwell WK, Cornelissen JHC (2014) Interactions between fine wood decomposition and flammability. Forests 4, 827-846. 
Table 1. Significant relationships (correlation coefficients, $R$, and $\mathbf{p}$-value) obtained between flammability variables and characteristics of leaf and litter bed (in bold: all species, in bold and italic: non-significant correlations but $\mathrm{R} \geq 0.5$, in italic: excluding the Cupressaceae species, in underlined: only the Cupressaceae species).

\begin{tabular}{|c|c|c|c|c|c|c|c|}
\hline & Lv_IF & Lv_TTI & Lv_FD & Lit_IF & Lit_TTI & Lit_FD & Lit_FS \\
\hline \multicolumn{8}{|c|}{ Leaf scale } \\
\hline FMC & NS & $0.65 ; p=0.031$ & NS & & & & \\
\hline Sctc & NS & NS & NS & NS & $\underline{0.98 ; p=0.020}$ & NS & $0.52 ; p=0.049$ \\
\hline Stot & NS & NS & $-0.53 ; p=0.043$ & NS & NS & $\underline{0.99 ; p=0.010}$ & $0.97 ; p=0.025$ \\
\hline Thi & NS & $0.76 ; p=0.0009$ & NS & NS & NS & $0.72 ; p=0.002$ & NS \\
\hline $\mathbf{W}$ & NS & NS & $-0.54 ; p=0.040$ & NS & NS & NS & NS \\
\hline
\end{tabular}




\begin{tabular}{|c|c|c|c|c|c|c|c|}
\hline $\mathbf{V}$ & NS & NS & NS & NS & NS & NS & NS \\
\hline SVR & NS & NS & NS & NS & NS & NS & NS \\
\hline SLA & NS & $-0.54 ; p=0.038$ & $\underline{0.98 ; p=0.022}$ & NS & NS & NS & NS \\
\hline D & NS & NS & NS & NS & NS & NS & $-0.66 ; p=0.007$ \\
\hline \multicolumn{8}{|c|}{ Litter scale } \\
\hline$\% \mathrm{Ev}$ & & & & $-0.55 ; p=0.034$ & NS & NS & NS \\
\hline$\%$ Sca & & & & NS & NS & NS & NS \\
\hline$\% \mathrm{Cp}$ & & & & NS & NS & NS & NS \\
\hline$\% \mathrm{Cd}$ & & & & NS & NS & NS & $0.63 ; p=0.036$ \\
\hline
\end{tabular}


$\% \mathbf{F p}$

$\% \mathrm{Fd}$

$\% \mathrm{NC}$

BD
NS

$0.50 ; p=0.057$

NS

NS
$0.51 ; p=0.054$

NS

NS

NS
NS

NS

$0.55 ; p=0.032$

NS

NS

$0.58 ; p=0.022$

$0.50 ; p=0.057$

Lv: leaves, Lit: litter, IF: ignition frequency, TTI: time-to-ignition, FD: flaming duration, FS: flame spread, FMC: fuel moisture content, Sctc: leaf contact surface area, Stot: leaf total surface area, Thi: leaf thickness, W: leaf weight, V: leaf volume, SVR: leaf surface area to volume ratio, SLA: specific leaf area, D: leaf density, BD: litter bulk density, \%Ev: proportion of evergreen leaves, \%Sca: proportion of scale-leaves, \%Fp: proportion of fine particles, \%Cp: proportion of coarse particles, \% Fd: proportion of fine debris, \%Cd: proportion of coarse debris, \%NC: proportion of non-combustible particles. 
Table 2. Significant relationships (correlation coefficients, $\mathbf{R}$, and p-value) obtained between leaf and litter bed flammability variables (in bold: all species, in italic: excluding the Cupressaceae species, in underlined: only the Cupressaceae species).

\begin{tabular}{ccccccc}
\hline & Lv_IF & Lv_TTI & Lv_FD & Lit_IF & Lit_TTI & Lit_FD \\
\hline Lv_IF & & $-0.71 ; p=0.014$ & NS & NS & NS & NS \\
Lv_TTI & $-0.71 ; p=0.014$ & & NS & $-0.68 ; p=0.023$ & NS & NS \\
Lv_FD & NS & NS & & NS & NS & NS $=\mathbf{0 . 0 2 4}$ \\
Lit_IF & NS & $-0.68 ; p=0.023$ & NS & & NS & NS \\
Lit_TTI & NS & NS & NS & NS & & 0.59;p=0.021 \\
Lit_FD & NS & $\mathbf{0 . 5 8} ; \mathbf{p = 0 . 0 2 4}$ & NS & $\mathbf{0 . 5 9} ; \mathbf{p}=\mathbf{0 . 0 2 1}$ & NS & NS \\
Lit_FS & NS & NS & NS & $0.99 ; p=0.0066$ & $0.96 ; p=0.041$ & NS \\
\hline
\end{tabular}

Lv: leaves, Lit: litter, IF: ignition frequency, TTI: time-to-ignition, FD: flaming duration, FS: flame spread. 
Table 3. Spearman's rank-order correlation between the leaf and litter flammability rankings of species

$\mathrm{H}_{0}$ : no association between the two variables; $\rho$ : Spearman's correlation coefficient, $\mathrm{P}$ : $\mathrm{p}$ value; IF: ignition frequency, TTI: time to ignition, FD: flaming duration

\begin{tabular}{ll} 
Ranking of species & Spearman's rank-order correlation \\
\hline Live leaf-Litter (all variables) & $\rho=0.17 ; \mathrm{P}=0.52$ : very weak \\
Leaf-Litter IF & $\rho=0.45 ; \mathrm{P}=0.052$ : moderate \\
Leaf-Litter TTI & $\rho=0.09 ; \mathrm{P}=0.77$ : very weak \\
Leaf-Litter FD & $\rho=-0.31 ; \mathrm{P}=0.25:$ weak \\
\hline
\end{tabular}

